\title{
Astrocytic Regulation of Sleep Processes
}

\author{
Lukas Ian Schmitt • Ralf Dieter Wimmer
}

Published online: 22 January 2015

(C) Springer International Publishing AG 2015

\begin{abstract}
It is increasingly evident that astrocytes, once considered primarily a passive support cell type, in fact respond to and regulate neurotransmission to influence information processing and behavior. Although astrocytes are not electrically excitable, they express a variety of receptors that produce calcium responses able to propagate within and between astrocytes. This form of signaling occurs on spatial and temporal scales distinct from those of neuronal activity, potentially allowing astrocytes to locally regulate synaptic and network activity over extended time periods. Perhaps the best studied example of this regulation is the control of sleep homeostasis by astrocytes. Astrocyte-derived adenosine causes an increase in sleep pressure leading to increased slow wave activity and extended recovery sleep. Despite its established importance for the sleep homeostat, however, the roles of astrocytes in other sleep-associated processes are only beginning to be understood.
\end{abstract}

Keywords Slow wave activity · Memory consolidation · Homeostasis $\cdot$ Adenosine $\cdot$ GAT $\cdot$ Lactate

\section{Introduction}

Sleep is a highly conserved behavior that is thought to be critical for normal function of the nervous system [1-5]. Astrocytes, the major glial support cell within the brain, have recently been shown to play a key role in regulating sleep and modulating synaptic and network activity to drive the homeostatic sleep response. The functions in which these cells have

This article is part of the Topical Collection on Function of Sleep

L. I. Schmitt $(\square) \cdot$ R. D. Wimmer

The Neuroscience Institute, Department of Neuroscience and

Physiology, NYU Langone Medical Center, 522 First Avenue, 6th floor, New York, NY 10016, USA

e-mail: lukas.schmitt@nyumc.org

R. D. Wimmer

e-mail: ralf.wimmer@nyumc.org been implicated include the generation of oscillatory activity characteristic of sleep [6-8] and the sleep-dependent consolidation of declarative memory [9-11]. Astrocytes have a variety of means to influence these processes: First, they control the clearance of many neurotransmitters such as glutamate, allowing them to modulate the rate constants of neurotransmission and to influence the level of synaptic spillover, thereby modulating the activation of extra-synaptic receptors [12, 13]. Second, astrocytes can regulate neuronal energy levels by controlling the availability of lactate and other metabolic fuels that can affect memory consolidation [14]. Finally, astrocytes can regulate neuronal activity, vascular function, and the activity of other astrocytes through the release of signaling molecules, a phenomenon termed gliotransmission [4].

Central to the dynamic involvement of astrocytes in brain function is their capacity to respond to incoming signals in a manner similar to neurons: by integrating incoming information, processing it, and actively responding to it [15-18]. Astrocytes express a wide array of receptors that couple to distinct signaling cascades to produce downstream effects, including mobilization of calcium from intracellular stores, primarily the endoplasmic reticulum (ER) and mitochondria [19-21]. The resulting elevation in astrocytic calcium leads to the release of signaling molecules including amino acid (e.g., D-serine and glutamate), purine (e.g., adenosine triphosphate: ATP), and peptide transmitters (e.g., brain-derived neurotrophic factor: BDNF). As in neurons, this release is mediated through a variety of mechanisms, the most prominent of which is probably SNARE-dependent vesicular exocytosis $[11,22,23]$. The type and level of release for these transmitters depends on the degree of calcium elevation [16] and varies across brain regions [24].

In contrast to neurons, astrocytes are electrically inexcitable. Release from these cells depends on fluctuations in calcium that can be extremely local, potentially allowing astrocytic responses to be restricted to a single synapse [11, $15,25]$. The diverse array of receptor and transmitter combinations in astrocytes is consistent with this local regulation 
and is likely to reflect distinct functional involvement of these cells in different parts of the brain. However, despite the diversity in receptor-transmitter combinations, several key astrocytic signaling pathways have emerged both in the cortex as well as subcortical structures. These pathways appear to play key roles in regulating synaptic transmission. In particular, the release of ATP, which is rapidly converted to adenosine in the extracellular space, appears to be a common mechanism by which astrocytes regulate multiple aspects of synaptic transmission. It is increasingly evident that the homeostatic sleep response involves this astrocyte-derived adenosine. The importance of this pathway and of astrocytes in general for other aspects of sleep function remains an active area of investigation.

\section{Regulation of Cortical Oscillations by Astrocytes}

Synchronized cortical oscillations are complex phenomena, and the extent to which this form of network activity is controlled by local versus global mechanisms remains controversial. Increasing evidence, however, indicates that astrocytes are involved in patterning this type of cortical activity [7]. Activation of adenosine A1 (adorA1) receptors either in a sleep regulatory centers, such as the basal forebrain (BF [26, 27]), or directly in the cortex is sufficient to potentiate slow wave activity and promote sleep [28]. The capacity of astrocytes to provide a source of adenosine suggests that these cells could promote NREM through the activation of these receptors, potentially contributing to the homeostatic sleep response [29]. This hypothesis was tested in a mouse model in which astrocytic vesicular release is selectively disrupted. Attenuation of this form of gliotransmission has no effect on baseline sleep architecture, suggesting that astrocytic regulation through this pathway is not necessary for maintaining the circadian rhythm. Closer examination of the spectral power during NREM sleep revealed a reduction in the power of lowfrequency slow wave activity (If-SWA). This corresponds to synchronized cortical activity in the $0.5-1.5-\mathrm{Hz}$ frequency range, associated with up-down states occurring during NREM sleep $[6,30,31]$ indicating that gliotransmission plays a role in promoting network synchronization during sleep.

The homeostatic sleep response is characterized by both an increase in the duration of recovery sleep and higher slow wave activity (SWA, $0.5-4 \mathrm{~Hz}$ ), also called delta activity [32]. Cortical delta activity is a well-established marker of sleep pressure that increases with progressive wakefulness and is associated with lower sleep latency following sleep deprivation. The elevation of this marker of sleep pressure is blunted by disrupting gliotransmission. Indeed, sleep deprivation accentuated the reduction in slow wave power in mice lacking normal gliotransmission while blunting the increase in sleep time following deprivation, indicating that astrocytic release is involved in maintaining sleep homeostasis [30]. This pathway has also been implicated in the increased sleep pressure associated with inflammatory responses [33], and in the antidepressant effect of sleep deprivation [34], both of which are reduced in the absence of normal gliotransmission. Chronic application of adenosine receptor antagonists phenocopies many effects of disrupted gliotransmission, suggesting that adenosine is the major transmitter through which astrocytes regulate sleep homeostasis and related processes [35].

Reduced gliotransmission has also been shown to inhibit low-frequency cortical oscillations and to decrease the frequency of up-down state transitions in individual neurons [6]. This effect was due to reduced NMDA receptor activation since blocking these receptors reduced slow oscillations to a greater degree in wild-type (WT) mice compared with mice lacking normal gliotransmission. Application of exogenous Dserine, which is also known to be released from astrocytes [36-38], partially rescues this effect suggesting that this gliotransmitter may be involved in the reduction of slow wave oscillations. Reduced D-serine may not completely account for the observed change in LTP, however, because suppression of gliotransmission also results in lower surface expression of NMDAR receptor subunits [6].

Despite the clear role of adenosine in inducing NREM sleep and promoting slow wave activity, changes in astrocytederived adenosine have not been shown to directly induce slow wave oscillations. Interestingly, however, the effect of the adorA1 antagonist cyclopentyl-1,3-dimethylxanthine (CPT) on cortical activity is suppressed in the absence of normal gliotransmission, indicating that the level of tonic adenosine is reduced in this model. This difference is potentiated by prior sleep deprivation [39] providing further evidence that astrocytic modulation through adenosine is driven by wakefulness. The possibility therefore remains that changes in purinergic signaling by astrocytes can play a role in potentiating slow wave oscillations. This possibility is supported by the observation that activating astrocytes can elicit cortical up states in the slice preparation via purinergic modulation [40]. A recent study suggested that astrocytes may also be involved in driving synchronization through an indirect pathway by activating adorA1 receptors (adorA1Rs) [41]. Although classically associated with presynaptic and somatic effects, adorA1Rs are highly enriched in postsynaptic fractions [42] and may regulate this subcellular compartment as well. This study demonstrated that the lower surface expression of NMDAR receptors produced by disrupting gliotransmission was rescued by incubation with the adorA1R agonist 2-chloro-N(6)cyclopentyladenosine (CCPA). Conversely, incubating slices in $200 \mathrm{nM}$ CPT reduced both NR2A and NR2B surface expression. These effects were functionally important since they led to a higher $\alpha$-amino-3-hydroxy-5-methyl-4isoxazolepropionic acid (AMPA)/NMDA receptor ratio as well 
as a decrease in the NMDA receptor components of miniature EPSCs [41]. Further investigations showed that the effect of adorA1R activation was mediated by src/fyn-dependent phosphorylation of NMDA receptor subunits, which led to a reduction in the internalization rate causing greater surface stability of these receptors (Fig. 1).

\section{Wakefulness-Dependent Changes in Astrocyte-Derived Adenosine Regulate Sleep}

Astrocytes regulate the level of extracellular adenosine through multiple mechanisms including active release and passive, concentration-dependent clearance [43-45]. Although neurons are also capable of releasing adenosine, particularly under conditions of metabolic stress [46], it is unclear to what extend this release contributes to tonic or wakefulness-dependent changes in adenosine. Cytosolic adenosine in neurons is relatively low under physiological conditions, suggesting that vesicular loading would be relatively inefficient, leading to rapid depletion upon repeated activation $[47,48]$. The level of cytosolic adenosine in astrocytes is variable and can be dynamically modulated by differential expression of adenosine kinase (ADK), which phosphorylates adenosine to 5 '-adenosine monophosphate (AMP) [49]. Expression of this enzyme is decreased following brain injury, potentially providing a neuroprotective increase in extracellular adenosine although this change is later reversed [50]. The relatively low level of ADK in neurons, however, leaves open the possibility that adenosine is released from these cells via passive transport. A recent study employing amperometric biosensors to directly measure adenosine demonstrated that the neuronal release of adenosine generated by metabolic activity can indeed provide a source of adenosine [51]. This release occurred following stimulation of axons within the hippocampus and was mediated by transport through passive equilibrative nucleoside transporter 1 (ENT1). Although this release was rapid and activity dependent, it did not account for a major portion of the adenosine released in response to stimulation suggesting that multiple mechanisms were involved. This second, slower component of the adenosine response was reduced in the absence of the 5 '-ectonucleotidase CD73 suggesting that it required conversion of metabolic precursors of adenosine. The authors suggested that ATP might be converted to adenosine since CD73 catalyzes the rate-limiting step in this pathway. Several lines of evidence indicate that extracellular hydrolysis of ATP provides a major source of extracellular adenosine [52] and that ATP is predominantly released from astrocytes, rather than neurons suggesting that this activity-dependent increase in adenosine is at least partially astrocyte dependent.

Once in the extracellular space, adenosine can activate several classes of GPCRs including Gi-coupled adorA1R and Gscoupled adenosine A2 receptors (adorA2R). AdorA2R are further subdivided into two classes, the adorA2a and adorA2b receptors, which have distinct functions and different patterns of expression [53]. The adorA1R shows high and broad expression in multiple brain regions $[54,55]$. In contrast, the

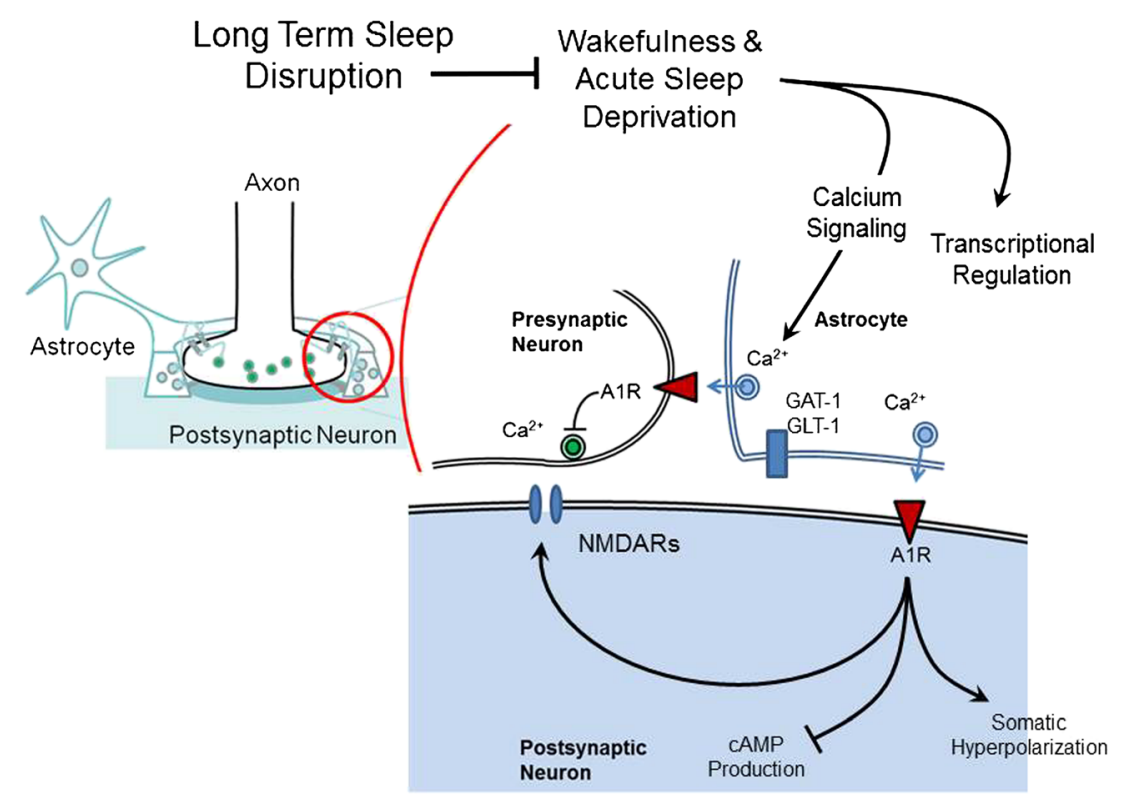

Fig. 1 Mechanisms of astrocytic sleep modulation: Astrocytes can modulate sleep-associated processes including sleep homeostasis, sleep depth, and sleep-dependent memory consolidation. While the mechanisms underlying these effects are not completely understood, a variety of pathways has been identified that are modulated by vigilance state and through which astrocytes can control synaptic and neuronal activity. These include release of transmitters, particularly ATP, which can act on pre- and postsynaptic AdorA1 receptors following conversion to adenosine, leading to a variety of effects. Astrocytes can also indirectly control the activation of extra-synaptic receptors by changing the expression of transporters such as GAT-1 and GLT-1 to modulate synaptic spillover for GABA and glutamate, respectively 
expression of the adorA2a receptor within the brain is primarily restricted to the striatum and nucleus accumbens. Activation of adorA1R can reduce neuronal excitability by hyperpolarizing neurons and can modulate synaptic transmission by suppressing vesicular release [56]. This pathway plays a key role in neuroprotection under pathological conditions, such as seizure and stroke, during which the increase in intracellular adenosine causes large-scale release through ENTs [49]. Under physiological conditions, however, adenosine is taken up by ENT1, and blocking these transporters has been shown to increase extracellular adenosine $[29,52,57]$.

In addition to its involvement in neuroprotection, adenosine is currently the best established mediator of the homeostatic sleep drive in mammals $[44,58,59]$ and more broadly a key player in synchronizing neuronal network activity. Indeed, caffeine, the most commonly used psychoactive substance, is thought to produce its wakefulness-promoting and stimulant effects primarily by blocking adorA1 and adorA2a receptors [60]. Conversely, adenosine receptor agonists promote sleep when provided centrally. This effect is thought to be at least partially mediated by adorA1R on acetylcholine neurons projecting to the cortex from within the basal forebrain (BF) [27] and from the laterodorsal tegmental nucleus (LDT). Cholinergic projections from these nuclei are a key part of the ascending arousal system responsible for maintaining the desynchronized patterns of brain activity associated with wakefulness and rapid eye movement (REM) sleep. Microdialysis and biosensor based measurements in the BF and cortical regions to which it projects show that levels of adenosine follow a diurnal rhythm [61] and increase during sleep deprivation $[62,63]$.

Within the BF, application of the adorA1R agonist N6cyclohexyladenosine (CHA) decreases single unit activity of wake-active neurons [64]. Conversely, application of the selective adorA1 antagonist CPT or knockdown of A1 receptors promotes wakefulness and increases firing rates of wakeactive neurons $[65,66]$. Knocking down adorA1R in the BF also prevents sleep deprivation-associated increases in SWA/ delta activity [66]. Conditional knockout of adorA1R in calcium kinase II-expressing neurons also leads to significant disruption of sleep homeostasis [3]. The effect of adenosine on firing rates of neurons in the $\mathrm{BF}$ is thought to be primarily mediated by direct modulation of neuronal excitability through somatic adorA1R. Studies from Arrigoni and others have demonstrated that this effect is due to hyperpolarization [65] and increased shunting inhibition produced by $G$ proteincoupled inward rectifying potassium channels (GIRKs, [67]). Application of adenosine and adorA1 agonists to the magnocellular preoptic nucleus and substantia innominata, the main wake-active portions of the $\mathrm{BF}$, activates an inwardly rectifying potassium current [68]. Interestingly, this current is present in cholinergic neurons but absent in putative GABAergic interneurons, which instead display reduced firing rate due to inhibition of the hyperpolarizationactivated cation current (h current) normally present in this cell type [69]. Activation of GIRK channels by adorA1R is common to many cell types throughout the cortex and varies systematically with passive membrane properties [70], suggesting that it plays a role in inhibiting excitatory neurotransmission within a variety of circuits [71].

In addition to its somatic inhibitory effects, adenosine can inhibit acetylcholine release by acting on presynaptic terminals $[26,27]$. Adenosine levels increase in the cortex following extended sleep deprivation, suggesting that presynaptic inhibition in the cortex may also be involved in promoting sleep. This idea is supported by a recent study showing that local application of adorA1R agonists in the prefrontal cortex, an area that is not essential for sleep cycle generation, is sufficient to decrease arousal and increase SWA [28]. These effects were associated with a reduction in acetylcholine, suggesting that they were due to suppression of BF projections through a reduction of transmitter release. AdorA1R produces this effect by decreasing 5 'cyclic AMP (cAMP) production resulting in reduced sensitivity of voltage-gated calcium channels to depolarization. Further evidence for the role of this type of presynaptic inhibition in the sleep-inducing effects of adenosine comes from studies of mice expressing a mutant form of presynaptic, voltage-gated calcium channel $\left(\mathrm{Ca}_{\mathrm{v}} 2.1,[72]\right)$. This mutant, known as Cacnala $\mathrm{R} 192 \mathrm{Q}$, expresses a version of $\mathrm{Ca}_{\mathrm{v}} 2.1$ that is less effectively modulated by changes in cAMP. These mice are less sensitive to the sleep-promoting effects of adorA1 agonist and show reduced sleep pressure in response to sleep deprivation [72].

Astrocytes provide a major source of extracellular adenosine through multiple pathways, and astrocyte-derived adenosine is increased following sleep deprivation in both the cortex and hippocampus [39]. This suggests that wakefulness-dependent changes in adenosine signaling occur broadly throughout the CNS to promote sleep and that astrocytes play a key role in controlling modulation by this pathway. Because adenosine receptors can couple to different signaling pathways $[9,43$, 73], however, the precise impact of these changes is likely to vary depending on the brain region, cell type, and the subcellular localization of the receptor [73]. Astrocytic modulation through this pathway could therefore lead to a diverse array of effects on brain function in response to sleep loss.

\section{Role of Astrocytes in Thalamocortical Dynamics}

Thalamocortical networks underlie the generation of several oscillations characteristic for sleep, including delta oscillations and spindles $(10-15 \mathrm{~Hz})$ [74]. Connectivity between thalamocortical (TC) relay cells and neurons of the thalamic reticular nucleus (TRN), the major inhibitory source of the thalamus, plays a crucial role in the generation of these oscillations $[75,76]$. Both spindle and delta oscillations arise from 
a combination of intrinsic channel properties and local TCTRN connectivity. In wakefulness, TC neurons are thought to faithfully relay incoming synaptic input to the cortex. During sleep, thalamic neurons become progressively hyperpolarized, switching their firing mode from tonic to burst discharge, enabling them to promote oscillatory activity. Bursting results from the activation of voltage-gated $\mathrm{Ca}^{2+}$ channels of the $\mathrm{T}$ type ( $\mathrm{T}$ channels) that are inactivated at membrane potentials above $-65 \mathrm{mV}$ but recover from inactivation at more hyperpolarized potentials. In individual TC cells, oscillatory activity in the delta range can be generated by an interplay between $\mathrm{T}$ currents and $\mathrm{h}$ currents $[78,78]$. Interconnections with TRN neurons [79] as well as cortical input [80] are thought to be necessary for synchronization to generate large cortical delta oscillations as seen during sleep. In addition to $\mathrm{T}$ channels, TRN neurons express $\mathrm{Ca}^{2+}$-dependent smallconductance-type2 (SK2) $\mathrm{K}^{+}$channels, and their interaction allows for intrinsic oscillatory properties in the spindle frequency range [81]. TRN bursts cause strong inhibitory postsynaptic currents (IPSCs) in TC cells resulting in rebound burst discharge. TC rebound bursting in turn reactivates TRN neurons, promoting intra-thalamic spindle oscillation, and relaying the oscillation to the cortex.

Given the high levels of GABA released by TRN terminals during burst discharge, clearance of the neurotransmitter from the synaptic cleft plays a critical role in limiting the activation of both synaptic and extra-synaptic receptors. In thalamus, clearance mostly depends on GABA transporters GAT-1 and GAT-3, which seem to be exclusively expressed in astrocytes in this brain region [82]. Indeed, GAT blockade prolongs IPSCs in different preparations [83, 84], and in thalamus specifically, it drastically prolongs TRN-mediated burst-induced IPSCs in VB neurons [85]. Additionally, a recent study by Christian and Huguenard indicated that astrocytes can prolong inhibition in the TRN through endogenous brainderived benzodiazepine-mimicking substances (endozepines) [86]. Although it is unclear whether astrocytes directly release endozepines or act upon neuronal sources, signaling through this pathway would enable region-specific modulation of IPSC duration. Given that IPSC amplitude and duration are thought to control timing and synchrony of sleep-related thalamocortical oscillations [87], astrocytic control of IPSC duration might represent a key mechanism by which astrocytes modulate sleep oscillations (Fig. 1).

\section{The Role of Astrocytes in Sleep-Dependent Memory Consolidation}

The biological effects of sleep are multifaceted. It is clear that sleep is critically involved in brain function and that among its most essential functions is the evolution of memory during NREM and REM sleep. Insufficient sleep has been shown to disrupt hippocampal-dependent memory performance in both rodents and humans $[88,89]$. Conversely, during sleep, declarative memory is stabilized and enhanced through a process known as consolidation [90]. Interestingly, this stabilization is not uniform since memories with increased emotional valence [91] or greater behavioral relevance for future reward [92] show a greater degree of retention compared with others. This has led to the concept of memory "triage," in which some hippocampal and cortical circuits that undergo plasticity during wakefulness are selectively enhanced relative to other inactive or less essential representations [93].

The association between increases in extracellular adenosine and higher SWA characteristic of higher sleep pressure suggests that wakefulness-dependent changes in this neuromodulator might play a role in coordinating neuronal networks leading to increased synchronization during subsequent NREM sleep. Since the activity underlying these rhythms is considered important for memory consolidation $[1,94,95]$ and memory triage [93], this implies that adenosine, and therefore by extension astrocytes, might be involved in regulating sleep-dependent plasticity. This idea is supported by the observation that astrocyte-derived adenosine can impact both basal synaptic transmission as well as certain forms of synaptic plasticity in situ [29].

Several mechanisms have been proposed to explain how memory changes occur at the cellular and synaptic level during sleep and how memory function is disrupted by sleep loss $[1,96]$. There are a variety of changes in gene expression [97-99], protein levels [100,101], receptor surface expression [102], synaptic structure [103], and metabolic activity [71, 104] associated with these behavioral states. Sleep deprivation produces a distinct set of changes which are likely to contribute to the deficits associated with sleep loss [10, 99, 105]. Among the core biological effects of sleep on neurological activity is the reduction in net potentiation across synapses relative to wakefulness. Changes in the relative level of potentiation are observed after even relatively short periods of sleep [94, 101]. This "synaptic down-scaling" counters the increase in ionotropic AMPA glutamate receptors in synaptic terminals over the subjective day. Sleep deprivation further increases levels of these receptors in synaptoneurosomes while also leading to increases in synaptic NMDA receptor levels, suggesting that this increased net potentiation is wakefulness dependent rather than a circadian variation in surface expression [105]. Upregulation of NMDA receptor surface expression, and in particular of NR2A-containing NMDA receptors, may be at least partially responsible for deficits associated with acute sleep deprivation since NR2A knockout mice showed a reduced deficit in hippocampal plasticity following sleep loss [102]. Given the capacity of astrocytederived adenosine to increase the stability of NMDA receptors, this effect could be at least partially due to increased adenosine associated with wakefulness. 
Table 1 Regional impact of astrocytic regulation during sleep

\begin{tabular}{|c|c|c|c|}
\hline Region & Mechanism & Effect & References \\
\hline Basal forebrain & AdorA1 receptor activation & $\begin{array}{l}\text { A. Increased somatic hyperpolarization and shunting inhibition } \\
\text { B. Inhibition of hyperpolarization activated cation-current }\end{array}$ & $\begin{array}{l}{[52]} \\
{[53]}\end{array}$ \\
\hline \multirow[t]{3}{*}{ Hippocampus } & \multirow[t]{2}{*}{ AdorA1 receptor activation } & A. Presynaptic inhibition of glutamatergic synapses & {$[23]$} \\
\hline & & B. Suppression of cAMP production & {$[96]$} \\
\hline & Regulation of metabolites & C. Support of long-term memory consolidation by astrocytic lactate & [3] \\
\hline \multirow[t]{5}{*}{ Cortex } & \multirow[t]{3}{*}{ AdorA1 receptor activation } & A. Somatic hyperpolarization and shunting inhibition & {$[54]$} \\
\hline & & B. Presynaptic inhibition of cholinergic terminals & {$[42,56]$} \\
\hline & & C. Stabilization of NMDA receptor surface expression & {$[30]$} \\
\hline & Control of synaptic spillover & D. Increase extrasynaptic glutamate during wakefulness compared with sleep & {$[100]$} \\
\hline & Regulation of metabolites & E. Convective exchange of metabolites is increased during sleep & {$[90]$} \\
\hline Thalamus & Control of synaptic spillover & A. Regulation of thalamic inhibition at the TC-TRN synapse via GAT transporters & {$[70]$} \\
\hline
\end{tabular}

In addition to increasing net potentiation, extended wakefulness is known to have a variety of effects on synaptic plasticity. Despite intense investigation, the molecular signaling mechanisms through which sleep deprivation controls plasticity remain incompletely understood. In a recent study, Vecsey and colleagues demonstrated that protein kinase A (PKA)dependent/cAMP-dependent synaptic plasticity is negatively affected by sleep deprivation [106]. The authors observed that a 5-h period of sleep loss produced deficits in multiple forms of LTP, including the form produced by theta burst stimulation, which are known to require PKA and cAMP-mediated transcriptional regulation. The authors further showed that enhancing signaling through this pathway by inhibiting phosphodiesterase 4 , an enzyme that degrades cAMP, rescued some of the deficits in LTP, and also improved performance in a hippocampal-dependent fear conditioning task [106]. Microarray data from multiple rodent studies implicate cAMPassociated gene networks in the response to sleep loss, providing further evidence that transcriptional regulation through this pathway is involved in sleep homeostasis [99].

The correlation between higher adenosine and the negative effects of sleep loss suggest the possibility that these deficits may involve the accumulated effect of astrocyte-derived adenosine. This idea is supported by the observation that dominant negative disruption of astrocytic exocytosis prevents the deficits in memory normally produced by sleep deprivation [30]. A similar protective effect can be obtained with chronic application of CPT to the CNS suggesting that the deficits in memory consolidation associated with sleep loss require the activation of adenosine receptors [30]. Because adorA1R is frequently Gi coupled, this effect may be due to the reduction of cAMP in the postsynaptic terminal. Consistent with this hypothesis, Florian et al. showed that the deficits in cAMPdependent LTP resulting from sleep deprivation were absent in mice which lacked normal gliotransmission and were also blocked by CPT [107]. Similar effects were also observed in a mouse model in which astrocytic release was disrupted through the expression of tetanus toxin, a manipulation which also modulated gamma oscillations [108]. These results strongly suggest that astrocytes regulate both synaptic transmission and plasticity in the hippocampus through the activation of adorA1R. Interestingly, protracted sleep restriction over weeks prevents wakefulness-dependent elevation of astrocyte-derived adenosine within the hippocampus, potentially to reduce the disruptive influence of this pathway on hippocampal function [109].

\section{Conclusion}

Astrocytes are no longer simply the "glue" of the brain. Rather than merely providing the interstitial binding that isolates synapses and maintains the environment for neurons, it is increasingly clear that these cells play an active role in brain function, including sleep-related processes. Although astrocytes are clearly involved in modulating synaptic transmission and neuronal activity, their responses occur in a very different temporal and spatial domain relative to neurons. The highly localized response and slow activation and propagation of astrocytic calcium signals suggest that these cells are well placed to integrate local activity over seconds or longer. It has been suggested that astrocytic regulation of activity over these timescales contributes to synchronization of brain activity [29], potentially allowing these cells to influence slow network interactions such as the generation of cortical up states [40]. Changes in transmitter release and transporter activity within astrocytes may occur over even more protracted timescales, and differential regulation of clearance produced by these changes has also been suggested to play a role in sleep regulation $[110,111]$. Long-term changes in astrocytic release underlie the well-described role of astrocyte-derived adenosine in the regulation of sleep. This and related processes influence many state-specific changes in synaptic and metabolic activity allowing short-range 
modulation by the astrocyte to impact plasticity and network function across many parts of the brain (Table 1) and thus to influence multiple aspects of sleep function. The involvement of astrocytes in the regulation of sleep homeostasis suggests that their influence may extend even further, potentially encompassing essential, sleep-related processes such as the consolidation of memory.

\section{Compliance with Ethics Guidelines}

Conflict of Interest Lukas Ian Schmitt and Ralf Dieter Wimmer declare that they have no conflict of interest.

Human and Animal Rights and Informed Consent This article does not contain any studies with human or animal subjects performed by any of the authors.

\section{References}

1. Diekelmann S, Born J. The memory function of sleep. Nat Rev Neurosci [Internet]. 2010;11(2):114-26. Nature Publishing Group, [cited 2011 Jul 6], Available from: http://www.ncbi.nlm.nih.gov/ pubmed/20046194.

2. Banks S, Dinges DF. Behavioral and physiological consequences of sleep restriction. J Clin Sleep Med [Internet]. 2007;3(5):519-28. Available from: http://www.pubmedcentral.nih.gov/articlerender. fcgi? artid $=1978335 \&$ tool $=$ pmcentrez\&rendertype $=$ abstract .

3. Bjorness TE, Kelly CL, Gao T, Poffenberger V, Greene RW. Control and function of the homeostatic sleep response by adenosine A1 receptors. J Neurosci [Internet]. 2009;29(5):1267-76. [cited 2011 Jul 19], Available from: http://www.pubmedcentral.nih.gov/ articlerender.fcgi artid $=2754857 \&$ tool $=$ pmcentrez\&rendertype $=$ abstract.

4. Cirelli C, Tononi G. Is sleep essential. PLoS Biol [Internet]. 2008;6(8):e216. [cited 2014 Jul 20], Available from: http://www. pubmedcentral.nih.gov/articlerender.fcgi? artid $=2525690 \&$ tool $=$ pmcentrez\&rendertype $=$ abstract.

5. Hobson JA, Pace-Schott EF. The cognitive neuroscience of sleep: neuronal systems, consciousness and learning. Nat Rev Neurosci [Internet]. 2002;3(9):679-93. [cited 2011 Jul 19], Available from: http://www.ncbi.nlm.nih.gov/pubmed/12209117.

6. Fellin T, Halassa MM, Terunuma M, Succol F, Takano H, Frank M, et al. Endogenous nonneuronal modulators of synaptic transmission control cortical slow oscillations in vivo. Proc Natl Acad Sci U S A [Internet]. 2009;106(35):15037-42. Available from: http://www. pubmedcentral.nih.gov/articlerender.fcgi?artid $=2736412 \&$ tool $=$ pmcentrez\&rendertype $=$ abstract.

7. Halassa MM. Thalamocortical dynamics of sleep: roles of purinergic neuromodulation. Semin Cell Dev Biol [Internet]. 2011;22(2):245-51. Elsevier Ltd, [cited 2013 Nov 15], Available from: http://www.pubmedcentral.nih.gov/articlerender.fcgi?artid= 3070804\&tool=pmcentrez\&rendertype $=$ abstract.

8. Parri HR, Gould TM, Crunelli V. Spontaneous astrocytic Ca2+ oscillations in situ drive NMDAR-mediated neuronal excitation. Nat Neurosci [Internet]. 2001;4(8):803-12. Available from: http:// www.ncbi.nlm.nih.gov/pubmed/11477426.

9. Halassa MM, Fellin T, Haydon PG. The tripartite synapse: roles for gliotransmission in health and disease. Trends Mol Med [Internet]. 2007;13(2):54-63. [cited 2013 Nov 10], Available from: http:// www.ncbi.nlm.nih.gov/pubmed/17207662.
10. Havekes R, Vecsey C, Abel T. The impact of sleep deprivation on neuronal and glial signaling pathways important for memory and synaptic plasticity. Cell Signal [Internet]. 2012;24(6):1251-60. [cited 2013 Nov 19], Available from: http://www.sciencedirect.com/ science/article/pii/S0898656812000678.

11. Parpura V, Heneka MT, Montana V, Oliet SHR, Schousboe A, Haydon PG, et al. Glial cells in (patho)physiology. J Neurochem [Internet]. 2012;121(1):4-27. [cited 2013 Nov 7], Available from: http://www.pubmedcentral.nih.gov/articlerender.fcgi?artid= 3304021\&tool=pmcentrez\&rendertype $=$ abstract.

12. Danbolt NC. Glutamate uptake. Prog Neurobiol [Internet]. 2001;65(1):1-105. Available from: http://www.pubmedcentral.nih. gov/articlerender.fcgi ?artid=2775085\&tool= pmcentrez\&rendertype $=$ abstract.

13. Nam HW, McIver SR, Hinton DJ, Thakkar MM, Sari Y, Parkinson FE, et al. Adenosine and glutamate signaling in neuron-glial interactions: implications in alcoholism and sleep disorders. Alcohol Clin Exp Res [Internet]. 2012;36(7):1117-25. [cited 2013 Nov 26], Available from: http://www.pubmedcentral.nih.gov/articlerender. fcgi?artid $=3349794 \&$ tool=pmcentrez\&rendertype $=$ abstract.

14. Suzuki A, Stern SA, Bozdagi O, Huntley GW, Walker RH, Magistretti PJ, et al. Astrocyte-neuron lactate transport is required for long-term memory formation. Cell [Internet]. 2011;144(5):810 23. Elsevier Inc., [cited 2011 Jul 15], Available from: http://www. pubmedcentral.nih.gov/articlerender.fcgi? $\operatorname{artid}=3073831 \&$ tool $=$ pmcentrez\&rendertype $=$ abstract.

15. Fellin T, Carmignoto G. Neurone-to-astrocyte signalling in the brain represents a distinct multifunctional unit. J Physiol [Internet]. 2004;559(Pt 1):3-15. [cited 2011 Jul 22], Available from: http:// www.pubmedcentral.nih.gov/articlerender.fcgi? artid= $1665073 \&$ tool $=$ pmcentrez\&rendertype $=$ abstract.

16. Parpura V, Zorec R. Exocytotic release from astrocytes. Brain Res Rev [Internet]. 2010;63(1-2):83-92. Elsevier B.V., [cited $2011 \mathrm{Jul}$ 28], Available from: http://www.pubmedcentral.nih.gov/ articlerender.fcgi artid $=2862866 \&$ tool $=$ pmcentrez\&rendertype $=$ abstract.

17. Zhang Q, Haydon PG. Exocytotic release from astrocytes. J Neural Transm [Internet]. 2005;112(1):121-5. [cited 2013 Nov 26], Available from: http://www.ncbi.nlm.nih.gov/pubmed/15599610.

18. Halassa MM, Haydon PG. Integrated brain circuits: astrocytic networks modulate neuronal activity and behavior. Annu Rev Physiol [Internet]. 2010;72:335-55. [cited 2011 Jul 27], Available from: http://www.pubmedcentral.nih.gov/articlerender.fcgi?artid= 3117429\&tool $=$ pmcentrez\&rendertype $=$ abstract.

19. Berridge MJ. Calcium microdomains: organization and function. Cell Calcium [Internet]. 2006;40(5-6):405-12. [cited 2013 Nov 14], Available from: http://www.ncbi.nlm.nih.gov/pubmed/ 17030366.

20. Zorec R, Araque A, Carmignoto G, Haydon PG, Verkhratsky A, Parpura V. Astroglial excitability and gliotransmission: an appraisal of $\mathrm{Ca} 2+$ as a signalling route. ASN Neuro [Internet]. 2012;4(2): 103-19. [cited 2013 Nov 7], Available from: http://www. pubmedcentral.nih.gov/articlerender.fcgi?artid $=3310306 \&$ tool $=$ pmcentrez\&rendertype $=$ abstract.

21. Pivneva T, Haas B, Reyes-Haro D, Laube G, Veh RW, Nolte C, et al. Store-operated $\mathrm{Ca} 2+$ entry in astrocytes: different spatial arrangement of endoplasmic reticulum explains functional diversity in vitro and in situ. Cell Calcium [Internet]. 2008;43(6):591-601. [cited 2013 Nov 14], Available from: http:/www.ncbi.nlm.nih.gov/ pubmed/18054077.

22. Newman EA. New roles for astrocytes: regulation of synaptic transmission. Trends Neurosci [Internet]. 2003;26(10):536-42. [cited 2013 Nov 26], Available from: http://www.ncbi.nlm.nih.gov/ pubmed/14522146.

23. Parpura V, Basarsky T, Liu F, Jeftinija K. Glutamate-mediated astrocyte-neuron signalling. Nature. 1994;369:744-7. [cited 2013 
Nov 26], Available from: http://www.nature.com/ abstractpagefinder/10.1038/369744a0.

24. Oberheim NA, Wang X, Goldman S, Nedergaard M. Astrocytic complexity distinguishes the human brain. Trends Neurosci [Internet]. 2006;29(10):547-53. [cited 2013 Nov 19], Available from: http://www.ncbi.nlm.nih.gov/pubmed/16938356.

25. Panatier A, Vallée J, Haber M, Murai KK, Lacaille J-C, Robitaille R. Astrocytes are endogenous regulators of basal transmission at central synapses. Cell [Internet]. 2011;146:785-98. [cited 2011 Aug 19], Available from: http://linkinghub.elsevier.com/retrieve/pii/ S0092867411008208.

26. Sperlágh B, Vizi ES. The role of extracellular adenosine in chemical neurotransmission in the hippocampus and basal ganglia: pharmacological and clinical aspects. Curr Top Med Chem [Internet]. 2011;11(8):1034-46. Available from: http://www.pubmedcentral. nih.gov/articlerender.fcgi? artid=3179034\&tool= pmcentrez\&rendertype $=$ abstract.

27. Brown RE, Basheer R, McKenna JT, Strecker RE, McCarley RW, Control of sleep and wakefulness. Physiol Rev [Internet]. 2012;92(3):1087-187. [cited 2013 Nov 6], Available from: http:// www.pubmedcentral.nih.gov/articlerender.fcgi?artid= 3621793\&tool $=$ pmcentrez\&rendertype $=$ abstract.

28. Van Dort CJ, Baghdoyan HA, Lydic R. Adenosine A(1) and A(2A) receptors in mouse prefrontal cortex modulate acetylcholine release and behavioral arousal. J Neurosci [Internet]. 2009;29(3):871-81. [cited $2011 \mathrm{Jul} 22$ ], Available from: http:/www.ncbi.nlm.nih.gov/ pubmed/19158311.

29. Pascual O, Casper KB, Kubera C, Zhang J, Revilla-Sanchez R, Sul J$\mathrm{Y}$, et al. Astrocytic purinergic signaling coordinates synaptic networks. Science [Internet]. 2005;310(5745):113-6. [cited 2011 Jun 21], Available from: http://www.ncbi.nlm.nih.gov/pubmed/16210541.

30. Halassa MM, Florian C, Fellin T, Munoz JR, Lee S-Y, Abel T, et al. Astrocytic modulation of sleep homeostasis and cognitive consequences of sleep loss. Neuron [Internet]. 2009;61(2):213-9. Elsevier Inc., [cited 2011, Available from: http://www. pubmedcentral.nih.gov/articlerender.fcgi?artid=2673052\&tool= pmcentrez\&rendertype $=$ abstract.

31. Destexhe A, Hughes SW, Rudolph M, Crunelli V. Are corticothalamic "up" states fragments of wakefulness? Trends Neurosci [Internet]. 2007;30(7):334-42. [cited 2011 Jun 15], Available from: http://www.pubmedcentral.nih.gov/articlerender. fcgi? artid $=3005711 \&$ tool $=$ pmcentrez\&rendertype $=$ abstract.

32. Basheer R, Strecker RE, Thakkar MM, McCarley RW. Adenosine and sleep-wake regulation. Prog Neurobiol [Internet]. 2004;73(6): 379-96. [cited 2011 Aug 8], Available from: http://www.ncbi.nlm. nih.gov/pubmed/15313333.

33. Nadjar A, Blutstein T, Aubert A, Laye S, Haydon PG. Astrocytederived adenosine modulates increased sleep pressure during inflammatory response. Glia [Internet]. 2013;61(5):724-31. [cited 2014 Oct 1], Available from: http://www.ncbi.nlm.nih.gov/ pubmed/23378051.

34. Hines DJ, Schmitt LI, Hines RM, Moss SJ, Haydon PG. Antidepressant effects of sleep deprivation require astrocytedependent adenosine mediated signaling. Transl Psychiatry [Internet. 2013;3(1):e212. Nature Publishing Group, [cited 2014 Sep 30], Available from: http://www.pubmedcentral.nih.gov/ articlerender.fcgi? artid $=3566717 \&$ tool $=$ pmcentrez $\&$ rendertype $=$ abstract.

35. Halassa MM, Fellin T, Haydon PG. Tripartite synapses: roles for astrocytic purines in the control of synaptic physiology and behavior. Neuropharmacology [Internet]. 2009;57(4):343-6. Elsevier Ltd, [cited 2013 Nov 14], Available from: http://www.pubmedcentral. nih.gov/articlerender.fcgi? artid=3190118\&tool= pmcentrez\&rendertype $=$ abstract.

36. Panatier A, Theodosis DT, Mothet J-P, Touquet B, Pollegioni L, Poulain DA, et al. Glia-derived D-serine controls NMDA receptor activity and synaptic memory. Cell [Internet]. 2006;125(4):775-84. [cited 2013 Nov 7], Available from: http://www.ncbi.nlm.nih.gov/ pubmed/16713567.

37. Henneberger C, Papouin T, Oliet S, Rusakov D. Long-term potentiation depends on release of D-serine from astrocytes. Nature [Internet]. 2010;463(7278):232-6. [cited 2013 Nov 22], Available from: http://www.nature.com/nature/journal/vaop/ncurrent/full/ nature08673.html.

38. Martineau M, Shi T, Puyal J, Knolhoff AM, Dulong J, Gasnier B, et al. Storage and uptake of D-serine into astrocytic synaptic-like vesicles specify gliotransmission. J Neurosci [Internet. 2013;33(8): 3413-23. [cited 2013 Nov 7], Available from: http://www. pubmedcentral.nih.gov/articlerender.fcgi?artid $=3772647 \&$ tool $=$ pmcentrez\&rendertype $=$ abstract.

39. Schmitt LI, Sims RE, Dale N, Haydon PG. Wakefulness affects synaptic and network activity by increasing extracellular astrocytederived adenosine. J Neurosci [Internet]. 2012;32(13):4417-25. [cited 2012 Mar 28], Available from: http://www.jneurosci.org/cgi/ doi/10.1523/JNEUROSCI.5689-11.2012.

40. Poskanzer KE, Yuste R. Astrocytic regulation of cortical UP states. Proc Natl Acad Sci U S A [Internet]. 2011;108(45):18453-8. [cited 2014 Sep 7], Available from: http://www.pubmedcentral.nih.gov/ articlerender.fcgi? artid $=3215035 \&$ tool $=$ pmcentrez\&rendertype $=$ abstract.

41. Deng Q, Terunuma M, Fellin T, Moss SJ, Haydon PG. Astrocytic activation of $\mathrm{A} 1$ receptors regulates the surface expression of NMDA receptors through a Src kinase dependent pathway. Glia [Internet]. 2011;59(7):1084-93. [cited 2011 Aug 11], Available from: http://www.pubmedcentral.nih.gov/articlerender.fcgi?artid= 3097531\&tool $=$ pmcentrez\&rendertype $=$ abstract.

42. Rebola N, Pinheiro PC, Oliveira CR, Malva JO, Cunha RA. Subcellular localization of adenosine A(1) receptors in nerve terminals and synapses of the rat hippocampus. Brain Res [Internet]. 2003;987(1):49-58. Available from: http://www.ncbi.nlm.nih.gov/ pubmed/14499945.

43. Cunha RA. Different cellular sources and different roles of adenosine, A1 receptor-mediated inhibition through astrocytic-driven volume transmission and synapse-restricted $\mathrm{A} 2 \mathrm{~A}$ receptor-mediated facilitation of plasticity. Neurochem Int [Internet]. 2008;52(1-2): 65-72. [cited 2013 Nov 18], Available from: http://www.ncbi.nlm. nih.gov/pubmed/17664029.

44. Blutstein T, Haydon PG. The importance of astrocyte-derived purines in the modulation of sleep. Glia [Internet]. 2013;61(2):129-39. [cited 2013 Nov 7], Available from: http://www.ncbi.nlm.nih.gov/ pubmed/23027687.

45. Palchykova S, Winsky-Sommerer R, Shen H-Y, Boison D, Gerling A, Tobler I. Manipulation of adenosine kinase affects sleep regulation in mice. J Neurosci [Internet]. 2010;30(39):13157-65. [cited 2011 Aug 12], Available from: http://www.pubmedcentral.nih.gov/ articlerender.fcgi? artid $=2950004 \&$ tool=pmcentrez\&rendertype $=$ abstract.

46. Wall MJ, Atterbury A, Dale N. Control of basal extracellular adenosine concentration in rat cerebellum. J Physiol [Internet]. 2007;582(Pt 1):137-51. [cited 2011 Sep 21], Available from: http://www.pubmedcentral.nih.gov/articlerender.fcgi? artid= 2075308\&tool $=$ pmcentrez\&rendertype $=$ abstract.

47. Lovatt D, Xu Q, Liu W, Takano T, Smith NA, Schnermann J, et al. Neuronal adenosine release, and not astrocytic ATP release, mediates feedback inhibition of excitatory activity. Proc Natl Acad Sci U S A [Internet]. 2012;109(16):6265-70. [cited 2013 Nov 13], Available from: http://www.pubmedcentral.nih.gov/articlerender. fcgi artid $=3341061 \&$ tool $=$ pmcentrez\&rendertype $=$ abstract.

48. Pearson T, Nuritova F, Caldwell D, Dale N, Frenguelli BG. A depletable pool of adenosine in area CA1 of the rat hippocampus. J Neurosci [Internet]. 2001;21(7):2298-307. Available from: http:// www.ncbi.nlm.nih.gov/pubmed/11264305. 
49. Latini S, Pedata F. Adenosine in the central nervous system: release mechanisms and extracellular concentrations. J Neurochem [Internet]. 2001;79(3):463-84. Available from: http://www.ncbi. nlm.nih.gov/pubmed/11701750.

50. Pignataro G, Maysami S, Studer FE, Wilz A, Simon RP, Boison D. Downregulation of hippocampal adenosine kinase after focal ischemia as potential endogenous neuroprotective mechanism. J Cereb Blood Flow Metab [Internet]. 2008;28(1):17-23. [cited 2013 Nov 15], Available from: http://www.ncbi.nlm.nih.gov/pubmed/ 17457365 .

51. Wall MJ, Dale N. Neuronal transporter and astrocytic ATP exocytosis underlie activity-dependent adenosine release in the hippocampus. J Physiol [Internet]. 2013;591(Pt 16):3853-71. [cited 2013 Nov 20], Available from: http://www.ncbi.nlm.nih.gov/pubmed/ 23713028.

52. Frenguelli BG, Wigmore G, Llaudet E, Dale N. Temporal and mechanistic dissociation of ATP and adenosine release during ischaemia in the mammalian hippocampus. J Neurochem [Internet]. 2007;101(5):1400-13. doi:10.1111/j.1471-4159.2006.04425.x. cited 2011 Sep 22.

53. Dunwiddie T, Masino S. The role and regulation of adenosine in the central nervous system. Annu Rev Neurosci [Internet]. 2001;24:3155. [cited 2013 Nov 25];31-55. Available from: http://www. annualreviews.org/doi/abs/10.1146/annurev.neuro.24.1.31.

54. Elmenhorst D, Meyer PT, Winz OH, Matusch A, Ermert J, Coenen $\mathrm{HH}$, et al. Sleep deprivation increases A1 adenosine receptor binding in the human brain, a positron emission tomography study. $\mathrm{J}$ Neurosci [Internet]. 2007;27(9):2410-5. [cited 2013 Nov 15]; Available from: http://www.ncbi.nlm.nih.gov/pubmed/17329439.

55. Fastbom J, Pazos A, Palacios JM. The distribution of adenosine A1 receptors and 5 '-nucleotidase in the brain of some commonly used experimental animals. Neuroscience [Internet]. 1987;22(3):813-26. Available from: http://www.ncbi.nlm.nih.gov/pubmed/2825070.

56. Dunwiddie TV, Fredholm BB. Adenosine A1 receptors inhibit adenylate cyclase activity and neurotransmitter release and hyperpolarize pyramidal neurons in rat hippocampus. J Pharmacol Exp Ther [Internet]. 1989;249(1):31-7. Available from: http://www. ncbi.nlm.nih.gov/pubmed/2565393.

57. Martín E, Fernández M, Perea G. Adenosine released by astrocytes contributes to hypoxia-induced modulation of synaptic transmission. Glia [Internet]. 2007;45:36-45. [cited 2013 Nov 21], Available from: http://onlinelibrary.wiley.com/doi/10.1002/glia.20431/full.

58. Díaz-Muñoz M, Salín-Pascual R. Purine molecules as hypnogenic factors role of adenosine, ATP, and caffeine. Cent Nerv Syst Agents Med Chem [Internet]. 2010;10(4):259-68. Available from: http:// www.ncbi.nlm.nih.gov/pubmed/20868361.

59. Porkka-Heiskanen T. Adenosine: a mediator of the sleep-inducing effects of prolonged wakefulness. Science (80-) [Internet]. 1997;276(5316):1265-8. [cited 2011 Jul 4], Available from: http:// www.sciencemag.org/cgi/doi/10.1126/science.276.5316.1265.

60. Ribeiro JA, Sebastião AM, de Mendonça A. Adenosine receptors in the nervous system: pathophysiological implications. Prog Neurobiol [Internet]. 2002;68(6):377-92. [cited 2013 Nov 18], Available from: http://linkinghub.elsevier.com/retrieve/pii/ S0301008202001557.

61. Murillo-Rodriguez E, Blanco-Centurion C, Gerashchenko D, SalinPascual R, Shiromani P. The diurnal rhythm of adenosine levels in the basal forebrain of young and old rats. Neuroscience [Internet]. 2004;123(2):361-70. [cited 2013 Nov 25];123(2):361-370. Available from: http://linkinghub.elsevier.com/retrieve/pii/ S0306452203007449.

62. Kalinchuk AV, McCarley RW, Porkka-Heiskanen T, Basheer R. The time course of adenosine, nitric oxide (NO) and inducible NO synthase changes in the brain with sleep loss and their role in the non-rapid eye movement sleep homeostatic cascade. J Neurochem [Internet]. 2011;116(2):260-72. [cited 2011 Sep 21], Available from: http://www.pubmedcentral.nih.gov/articlerender.fcgi?artid= 3042163\&tool=pmcentrez\&rendertype $=$ abstract.

63. Sims RE, Wu HHT, Dale N. Sleep-wake sensitive mechanisms of adenosine release in the basal forebrain of rodents: an in vitro study. PLoS One [Internet]. 2013;8:e53814. [cited 2013 Nov 17] Available from: http://www.pubmedcentral.nih.gov/articlerender.fcgi?artid= $3543262 \&$ tool $=$ pmcentrez\&rendertype $=$ abstract.

64. Alam MN, Szymusiak R, Gong H, King J, McGinty D. Adenosinergic modulation of rat basal forebrain neurons during sleep and waking: neuronal recording with microdialysis. J Physiol [Internet]. 1999;521(Pt 3):679-90. Available from: http://www. pubmedcentral.nih.gov/articlerender.fcgi?artid $=2269685 \&$ tool $=$ pmcentrez\&rendertype $=$ abstract.

65. Strecker RE, Morairty S, Thakkar MM, Porkka-Heiskanen T, Basheer R, Dauphin LJ, et al. Adenosinergic modulation of basal forebrain and preoptic/anterior hypothalamic neuronal activity in the control of behavioral state. Behav Brain Res [Internet]. 2000;115(2):183-204. Available from: http://www.ncbi.nlm.nih. gov/pubmed/11000420.

66. Thakkar MM, Winston S, McCarley RW. A1 receptor and adenosinergic homeostatic regulation of sleep-wakefulness: effects of antisense to the A1 receptor in the cholinergic basal forebrain. J Neurosci [Internet]. 2003;23(10):4278-87. Available from: http:// www.pubmedcentral.nih.gov/articlerender.fcgi?artid= 2002519\&tool=pmcentrez\&rendertype=abstract.

67. Trussell LO, Jackson MB. Adenosine-activated potassium conductance in cultured striatal neurons. Proc Natl Acad Sci U S A [Internet]. 1985;82(14):4857-61. Available from: http://www.ncbi. nlm.nih.gov/pubmed/2991897.

68. Arrigoni E, Rainnie DG, McCarley RW, Greene RW. Adenosinemediated presynaptic modulation of glutamatergic transmission in the laterodorsal tegmentum. J Neurosci [Internet]. 2001;21(3): 1076-85. Available from: http://www.ncbi.nlm.nih.gov/pubmed/ 11157094.

69. Arrigoni E, Chamberlin NL, Saper CB, McCarley RW. Adenosine inhibits basal forebrain cholinergic and noncholinergic neurons in vitro. Neuroscience [Internet]. 2006;40(2):403-13. [cited 2013 Nov 14] Available from: http://www.ncbi.nlm.nih.gov/pubmed/ 16542780

70. Van Aerde KI, Qi G, Feldmeyer D. Cell type-specific effects of adenosine on cortical neurons. Cereb Cortex [Internet]. 2013; [cited 2013 Nov 24]; Available from: http://www.cercor.oxfordjournals. org/cgi/doi/10.1093/cercor/bht274.

71. Porkka-Heiskanen T, Kalinchuk AV. Adenosine, energy metabolism and sleep homeostasis. Sleep Med Rev [Internet]. 2011;15(2):12335. Elsevier Ltd, [cited 2011 Jun 26], Available from: http://www. ncbi.nlm.nih.gov/pubmed/20970361.

72. Deboer T, van Diepen HC, Ferrari MD, Van den Maagdenberg AMJM, Meijer JH. Reduced sleep and low adenosinergic sensitivity in cacna1a R192Q mutant mice. Sleep [Internet]. 2013;36(1):12736. Available from: http://www.pubmedcentral.nih.gov/ articlerender.fcgi artid $=3524534 \&$ tool $=$ pmcentrez\&rendertype $=$ abstract.

73. Cordeaux Y, Ijzerman AP, Hill SJ. Coupling of the human A1 adenosine receptor to different heterotrimeric $\mathrm{G}$ proteins, evidence for agonist-specific $\mathrm{G}$ protein activation. $\mathrm{Br} \mathrm{J}$ Pharmacol [Internet]. 2004;143(6):705-14. [cited 2013 Nov 17], Available from: http:// www.pubmedcentral.nih.gov/articlerender.fcgi?artid= 1575922\&tool=pmcentrez\&rendertype $=$ abstract.

74. Crunelli V, David F, Lőrincz ML, Hughes SW. The thalamocortical network as a single slow wave-generating unit. Curr Opin Neurobiol [Internet]. 2015;31:72-80. [cited 2014 Sep 18], Available from: http://linkinghub.elsevier.com/retrieve/pii/ S0959438814001792.

75. Halassa MM, Siegle JH, Ritt JT, Ting JT, Feng G, Moore CI. Selective optical drive of thalamic reticular nucleus generates 
thalamic bursts and cortical spindles. Nat Neurosci [Internet]. 2011;14(9):1118-20. Nature Publishing Group, [cited $2011 \mathrm{Jul}$ 26], Available from: http://www.ncbi.nlm.nih.gov/pubmed/ 21785436.

76. Pinault D. The thalamic reticular nucleus: structure, function and concept. Brain Res Brain Res Rev. 2004;46:1-31.

77. McCormick D, Pape HC. Properties of a hyperpolarization-activated cation current and its role in rhythmic oscillation in thalamic relay neurones. J Physiol. 1990;431:291-38.

78. Jahnsen BYH, Llinas R. Ionic basis for the electroresponsiveness. J Physiol. 1984;349:227-47.

79. Steriade M. Grouping of brain rhythms in corticothalamic systems. Neuroscience [Internet]. 2006;137(4):1087-106. [cited 2011 Jun 14], Available from: http://www.ncbi.nlm.nih.gov/pubmed/ 16343791.

80. Steriade M, Dossi RC, Nuñez A. Network modulation of a slow intrinsic oscillation of cat thalamocortical neurons implicated in sleep delta waves: cortically induced synchronization and brainstem cholinergic suppression. J Neurosci [Internet]. 1991;11(10):3200-17. Available from: http://www.ncbi.nlm.nih.gov/pubmed/1941080.

81. Cueni L, Canepari M, Luján R, Emmenegger Y, Watanabe M, Bond $\mathrm{CT}$, et al. T-type Ca2+ channels, SK2 channels and SERCAs gate sleep-related oscillations in thalamic dendrites. Nat Neurosci [Internet]. 2008;11(6):683-92. [cited 2014 Sep 22], Available from: http://www.ncbi.nlm.nih.gov/pubmed/18488023.

82. Vitellaro-Zuccarello L, Calvaresi N, De Biasi S. Expression of GABA transporters, GAT-1 and GAT-3, in the cerebral cortex and thalamus of the rat during postnatal development. Cell Tissue Res [Internet]. 2003;313(3):245-57. [cited 2014 Oct 1], Available from: http://www.ncbi.nlm.nih.gov/pubmed/12898208.

83. Nusser Z, Naylor D, Mody I. Synapse-specific contribution of the variation of transmitter concentration to the decay of inhibitory postsynaptic currents. Biophys J [Internet]. 2001;80(3):1251-61. Available from: http://www.pubmedcentral.nih.gov/articlerender. fcgi?artid $=1301320 \&$ tool $=$ pmcentrez\&rendertype $=$ abstract.

84. Keros S, Hablitz JJ. Subtype-specific GABA transporter antagonists synergistically modulate phasic and tonic GABAA conductances in rat neocortex. J Neurophysiol [Internet]. 2005;94(3):2073-85. [cited 2014 Oct 1], Available http://www.ncbi.nlm.nih.gov/pubmed/ 15987761 .

85. Herd MB, Brown AR, Lambert JJ, Belelli D. Extrasynaptic GABA(A) receptors couple presynaptic activity to postsynaptic inhibition in the somatosensory thalamus. J Neurosci [Internet]. 2013;33(37):14850-68. [cited 2014 Oct 1], Available from: http:// www.ncbi.nlm.nih.gov/pubmed/24027285.

86. Christian CA, Huguenard JR. Astrocytes potentiate GABAergic transmission in the thalamic reticular nucleus via endozepine signaling. Proc Natl Acad Sci U S A [Internet]. 2013;110(50):2027883. [cited 2014 Oct 1], Available from: http://www.pubmedcentral. nih.gov/articlerender.fcgi? artid=3864346\&tool= pmcentrez\&rendertype $=$ abstract.

87. Huguenard JR, McCormick DA. Thalamic synchrony and dynamic regulation of global forebrain oscillations. Trends Neurosci [Internet]. 2007;30(7):350-6. [cited 2011 Jul 19], Available from: http://www.ncbi.nlm.nih.gov/pubmed/17544519.

88. Graves LA, Heller EA, Pack AI, Abel T. Sleep deprivation selectively impairs memory consolidation for contextual fear conditioning. Learn Mem [Internet]. 2003;10(3):168-76. [cited 2011 Jul 21]; Available from: http://www.pubmedcentral.nih.gov/articlerender. fcgi?artid $=202307 \&$ tool $=$ pmcentre $z \&$ rendertype $=$ abstract .

89. Yoo S-S, Hu PT, Gujar N, Jolesz FA, Walker MP. A deficit in the ability to form new human memories without sleep. Nat Neurosci [Internet]. 2007;10(3):385-92. [cited 2011 Aug 8], Available from: http://www.ncbi.nlm.nih.gov/pubmed/17293859.

90. Stickgold R, Walker MP. Sleep-dependent memory consolidation and reconsolidation. Sleep Med [Internet]. 2007;8(4):331-43. [cited
2011 Aug 7], Available from: http://www.pubmedcentral.nih.gov/ articlerender.fcgi? artid $=2680680 \&$ tool $=$ pmcentrez\&rendertype $=$ abstract.

91. Hu P, Stylos-Allan M, Walker MP. Sleep facilitates consolidation of emotional declarative memory. Psychol Sci [Internet]. 2006;17(10): 891-8. Available from: http://www.ncbi.nlm.nih.gov/pubmed/ 17100790

92. Fischer S, Born J. Anticipated reward enhances offline learning during sleep. J Exp Psychol Learn Mem Cogn [Internet]. 2009;35(6):1586-93. [cited 2013 Nov 25], Available from: http:// www.ncbi.nlm.nih.gov/pubmed/19857029.

93. Stickgold R, Walker MP. Sleep-dependent memory triage: evolving generalization through selective processing. Nat Neurosci [Internet]. 2013;16(2):139-45. [cited 2013 Nov 11], Available from: http:// www.ncbi.nlm.nih.gov/pubmed/23354387.

94. Nere A, Hashmi A, Cirelli C, Tononi G. Sleep-dependent synaptic down-selection (I): modeling the benefits of sleep on memory consolidation and integration. Front Neurol [Internet]. 2013; [cited 2013 Nov 15];4(September):143. Available from: http://www. pubmedcentral.nih.gov/articlerender.fegi?artid=3786405\&tool= pmcentrez\&rendertype $=$ abstract.

95. Inostroza M, Born J. Sleep for preserving and transforming episodic memory. Annu Rev Neurosci [Internet]. 2013;36:79-102. [cited 2013 Nov 7], Available from: http://www.ncbi.nlm.nih.gov/ pubmed/23642099.

96. Diekelmann S, Wilhelm I, Born J. The whats and whens of sleepdependent memory consolidation. Sleep Med Rev [Internet]. 2009;13(5):309-21. [cited 2013 Nov 7], Available from: http:// www.ncbi.nlm.nih.gov/pubmed/19251443.

97. Tononi G, Cirelli C. Modulation of brain gene expression during sleep and wakefulness: a review of recent findings. Neuropsychopharmacology [Internet]. 2001;25(5 Suppl):S28-35. Available from: http://www.ncbi.nlm.nih.gov/pubmed/11682270.

98. Romcy-Pereira RN, Erraji-Benchekroun L, Smyrniotopoulos P, Ogawa S, Mello CV, Sibille E, et al. Sleep-dependent gene expression in the hippocampus and prefrontal cortex following long-term potentiation. Physiol Behav [Internet]. 2009;98(1-2):44-52. Elsevier Inc, [cited 2011 Aug 24], Available from: http://www. pubmedcentral.nih.gov/articlerender.fcgi?artid $=2707503 \&$ tool $=$ pmcentrez\&rendertype $=$ abstract.

99. Wang H, Liu Y. Computational analysis of gene regulation in animal sleep deprivation. Physiol Genomics [Internet]. 2010;42:427-36. [cited 2013 Nov 26], Available from: http://physiolgenomics. physiology.org/content/42/3/427. short.

100. Gilestro G, Tononi G, Cirelli C. Widespread changes in synaptic markers as a function of sleep and wakefulness in Drosophila. Science. 2009;324(5923):109-12. [cited 2013 Nov 19], Available from: http://www.sciencemag.org/content/324/5923/109.short.

101. Vyazovskiy VV, Cirelli C, Pfister-Genskow M, Faraguna U, Tononi G. Molecular and electrophysiological evidence for net synaptic potentiation in wake and depression in sleep. Nat Neurosci [Internet]. 2008;11(2):200-8. [cited 2011 Jun 14], Available from: http://www.ncbi.nlm.nih.gov/pubmed/18204445.

102. Longordo F, Kopp C, Lüthi A. Consequences of sleep deprivation on neurotransmitter receptor expression and function. Eur J Neurosci [Internet]. 2009;29(9):1810-9. [cited 2013 Nov 14], Available from: http://doi.wiley.com/10.1111/j.1460-9568.2009.06719.x.

103. Bushey D, Tononi G, Cirelli C. Sleep and synaptic homeostasis: structural evidence in Drosophila. Science [Internet]. 2011;332(6037):1576-81. [cited 2013 Nov 11] Available from: http://www.pubmedcentral.nih.gov/articlerender.fcgi?artid= 3128387\&tool=pmcentrez\&rendertype $=$ abstract.

104. Xie L, Kang H, Xu Q, Chen MJ, Liao Y, Thiyagarajan M, et al. Sleep drives metabolite clearance from the adult brain. Science [Internet]. 2013;342(6156):373-7. [cited 2013 Nov 6], Available from: http://www.ncbi.nlm.nih.gov/pubmed/24136970. 
105. Kopp C, Longordo F, Nicholson JR, Lüthi A. Insufficient sleep reversibly alters bidirectional synaptic plasticity and NMDA receptor function. J Neurosci [Internet]. 2006;26(48):12456-65. [cited 2013 Nov 14], Available from: http://www.ncbi.nlm.nih.gov/pubmed/17135407.

106. Vecsey CG, Baillie GS, Jaganath D, Havekes R, Daniels A, Wimmer M, et al. Sleep deprivation impairs cAMP signalling in the hippocampus. Nature [Internet]. 2009;461(7267):1122-5. Nature Publishing Group, [cited 2013 Nov 6], Available from: http://www.pubmedcentral.nih.gov/articlerender.fcgi?artid= 2783639\&tool $=$ pmcentrez\&rendertype $=$ abstract

107. Florian C, Vecsey CG, Halassa MM, Haydon PG, Abel T. Astrocyte-derived adenosine and A1 receptor activity contribute to sleep loss-induced deficits in hippocampal synaptic plasticity and memory in mice. J Neurosci [Internet]. 2011;31(19):6956-62. [cited 2011 Jun 25], Available from: http://www.ncbi.nlm.nih.gov/ pubmed/21562257.

108. Lee HS, Ghetti A, Pinto-Duarte A, Wang X, Dziewczapolski G, Galimi F, Huitron-Resendiz S, Pina-Crespo JC, Roberts A. J, Verma
IM, Sejnowski TJ, Heinemann SF. Astrocytes contribute to gamma oscillations and recognition memory. Proc Natl Acad Sci [Internet]. 2014; [cited 2014 Jul 29]; Available from: http://www.pnas.org/cgi/ doi/10.1073/pnas.1410893111.

109. Clasadonte J, McIver SR, Schmitt LI, Halassa MM, Haydon PG. Chronic sleep restriction disrupts sleep homeostasis and behavioral sensitivity to alcohol by reducing the extracellular accumulation of adenosine. J Neurosci [Internet]. 2014;34(5):1879-91. Available from: http://www.pubmedcentral.nih.gov/articlerender.fcgi?artid= 3905149\&tool=pmcentrez\&rendertype $=$ abstract.

110. Dash MB, Douglas CL, Vyazovskiy VV, Cirelli C, Tononi G. Longterm homeostasis of extracellular glutamate in the rat cerebral cortex across sleep and waking states. J Neurosci. 2009;29(3):620-9.

111. Johnston MV, Ammanuel S, O’Driscoll C, Wozniak A, Naidu S, Kadam SD. Twenty-four hour quantitative-EEG and in-vivo glutamate biosensor detects activity and circadian rhythm dependent biomarkers of pathogenesis in Mecp2 null mice. Front Syst Neurosci. 2014;8(June):118. 